\title{
Aktivní prvky bezpečnosti v rámci výuky cykloturistiky na ZŠ a Š̌
}

\section{Active safety elements in teaching cycling in primary school}

\author{
Sylva Hřebíčková, Jan Ondráček, Jiří Palán
}

Fakulta sportovních studií Masarykovy univerzity, Brno

\begin{abstract}
Abstrakt
Cykloturistika se stává dominantní turistickou aktivitou. Žáci se mohou setkat s výukou cyklistiky především prostřednictvím cykloturistických kurzů. Jejich realizace je stále učiteli považována za rizikovou. Ve výzkumu jsme se zaměřili na aktivní složku bezpečnostního hlediska cyklistiky a cykloturistiky. Použili jsme metody pozorování, rozhovoru a anketního dotazníku. Výzkumu se účastnily tři různé skupiny. Výsledky naznačují zájem pedagogů i žáků o výuku cyklistiky nejen v rámci kurzů. Největšími bariérami jsou personálni zabezpečeni a úroveň jizdních dovedností žáků.
\end{abstract}

\begin{abstract}
Biking tourism is becoming the dominant tourist activity in the education of students to meet with teaching cycling courses primarily through cycling. Their implementation is still risky. In research we focused on the active component of the safety aspects of tourism and cycling. We used the method of observation, interview, and interview questionnaire. Our research involved three different groups of population. Results suggest teachers and students interested in learning not only in the cycling course. The most significant barrier form staffing levels and riding skills of students.
\end{abstract}

Klíčová slova: cykloturistika, pedagogika, bezpečnost

Key words: $\quad$ biking tourism, education, safety

\section{Úvod}

Cykloturistika se stává dominantníturistickou aktivitou (Ondráček a Hřebíčková, 2007). Cykloturistika je jedním z druhů cyklistiky, dle Vyškovského (1997) využívá k pohybu jízdního kola a jako turistika obsahuje tři základní složky (pohybovou, kulturně-poznávací a odborně technickou).

V rámci vzdělávání se žáci mohou setkat s výukou cyklistiky především prostřednictvím cykloturistických kurzů. Jejich realizace je stále učiteli považována za rizikovou (Kábrtová, 2010; Kalich, 2008; Koláček, 2010, Karas, 2010), proto jsme se ve výzkumu zaměřili na aktivní složku bezpečnostního hlediska provozování cykloturistiky.

Podle údajů, které uvádí Ministerstvo zdravotnictví České republiky, se Česká republika řadí mezi evropské státy s nejvyšší úmrtností dětí v důsledku úrazů. Úrazy tvoří vůbec nejčastější příčinu úmrtí dětí a mladých dospělých a třetí nejčastější přičinu úmrtí v celé populaci. Tato neprríznivá bilance se týká i cyklistiky. Pro ilustraci předkládáme statistiku za rok 2006, která uvádí 30 úmrtí dětí do 14 let, souvisejících s dopravou. $Z$ toho bylo 9 chodců, 16 cestujících v motorových vozidlech a 5 cyklistů. V poslední době je sice patrný trend poklesu úmrtí, nicméně celkový počet úrazů neklesá (zdroj: http://www.mzcr. $\mathrm{cz})$.

Rámcový vzdělávací program se bezpečností při pohybových činnostech věnuje v rámci vzdělávací oblasti „Člověk a zdraví“ (bezpečné chování v přírodě i silničním provozu v roli cyklisty). Podle platných norem vyžaduje personální zabezpečení akce (výletu s cyklistickou náplní) poměr 2 pedagogy na 10 žáků.

Problematikou bezpečnosti cyklistiky se kromě výše zmíněných autorů věnují i další práce. Karas (2010), Pucher a Buehler (2005) poukazují na důležitost pasivní ochrany, ale i výchovné působení školy a rodičů v rámci bezpečného chování v cyklistice. Problematice výchovy v turistice se věnují i Weiermair 
a Bieger (2005). Kromě uvedených studií jsme další, které by se věnovaly př́ímo analýze aktivní bezpečnosti ve školských zařízeních v ČR, nenašli.

Pod pojem aktivní bezpečnost řadíme ty prvky bezpečnosti, které pomáhají zabránit vzniku nehody (Palán, 2011). Mezi ně patří především dovednost ovládat jízdní kolo, kam spadá soubor dovedností označovaný jako technika jízdy jednotlivce. Do další skupiny patř́ technika jízdy skupiny (Ondráček a Hřebíčková, 2007). Tyto prvky jsou seřazeny v rámci obtížnosti v tab. 1. Řadíme sem i specifické činnosti, které jsou nutné pro realizaci cykloturistického výletu a které by žáci měli zvládnout $\mathrm{v}$ duchu odborně technické činnosti (Vyškovský, 1997). Náš výzkum byl zaměřen na subjektivní bariéry, které eliminují rizika plynoucí $\mathrm{z}$ objektivních přičin - nehody při jízdě v terénu způsobené například špatným stavem terénu, nepředvídatelnou událostí (Bořek, 2007).

Tab. 1 - Soubor dovedností k ovládání jízdního kola

\begin{tabular}{|l|l|l|}
\hline technika jízdy jednotlivce & technika jízdy skupiny & odborně-technické činnosti \\
\hline v př́mém směru & jízda ve dvojici vedle sebe & výměna duše a lepení duše \\
\hline zatáčení & jízda ve dvojici za sebou & nýtování řetězu \\
\hline sjezd & jízda ve skupině & mytí kola \\
\hline výjezd & signalizace & jednoduché opravy \\
\hline řazení & jízda po komunikaci & seř́zení kola a velké opravy \\
\hline brzdění & & \\
\hline překonávání překážek & & \\
\hline jízda v obtížném terénu & & \\
\hline jízda po komunikaci & & \\
\hline
\end{tabular}

\section{Cíl}

Cílem výzkumu bylo zjistit bariéry cykloturistiky v podobě vybraných prvků aktivní bezpečnosti a subjektivní vnímání úrovně dovedností jízdy na kole žáků středních (nižšího stupně) a základních škol.

\section{Metodika}

V rámci studia dostupné literatury jsme určili škálu dovedností, které jsou pro výuku jízdy na kole vhodné. Předvýzkum jsme prováděli v rámci testování kol na výstavě Sport life 2010 pozorováním techniky jízdy jezdců v terénu. Na základě pořízeného videozáznamu jsme určili a analyzovali základní dovednosti (viz tab. 1 - zvýrazněné položky). Z vytvořené hodnotící škály jsme pak určili základní dovednosti i nejčastější chyby v technice jízdy (technika sjezdů, výjezdů, řazení, brzdění). Tato zjištění jsme přenesli do konstrukce dotazníku pro žáky. Dotazníku předcházel nestrukturovaný rozhovor $\mathrm{s}$ učiteli, kteří kurzy cykloturistiky pořádají. Struktura páteřních témat rozhovoru vznikala na základě konzultací s odborníky z řad zkušených pedagogů tělesné výchovy vybraných škol. Rozhovory byly nahrávány na diktafon a posléze analyzovány.

Nejdřive jsme uvedli shodné rysy všech rozhovorů a shrnuli je do stručné charakteristiky. Dále jsme postupovali po okruzích otázek a srovnávali data získaná od různých pedagogů. Následně jsme výsledky uspořádali do uceleného textu. Zde jsme hledali shody i odlišnosti v jednotlivých výpovědích, abychom co nejobsáhleji zaznamenali výsledky své výzkumné činnosti.

Anketní dotazník pro žáky obsahoval 32 položek. První verzi jsme otestovali na vzorku pěti žáků z 6. tř́idy základní školy. Podle jejich připomínek k nejasnosti některých položek jsme anketní dotazník upravili do konečné podoby. Anketní dotazník obsahoval 2 otevřené a 30 uzavřených položek. U otevřených položek jsme požadovali jednoslovné doplnění. Celkem jsme získali ke zpracování 216 anketních dotazníků. 
Údaje z nashromážděných anketních dotazníků jsme vypisovali do záznamových archů. Použili jsme čárkovací metodu. Vzhledem k rozsahu výzkumného souboru jsme využili více záznamových archů. V tabulkách jsme uvedli absolutní četnost získaných dat, přepočty na procenta, u některých položek i kumulativní četnosti a nejčastější hodnoty. Grafy jsme do práce vložili k zpřehlednění výsledků.

Validitu dat jsme u všech metod výzkumu zajistili konzultací s pedagogy, kteří mají bohaté zkušenosti s výukou cyklistiky ve škole nebo realizují cykloturistické kurzy, a s trenéry cyklistiky (horských kol) mládežnických kategorií.

\section{Charakteristika souboru}

Pozorování se zúčastnilo celkem 40 testovacích jezdců (mužů) ve věkovém rozmezí 18 až 50 let. Rozhovor probíhal s učiteli, kteří vyučují tělesnou výchovu (4 ženy a 4 muži ve věkovém rozmezí od 35 do 54 let). Hlavní výzkum v podobě dotazníkového šetření byl prováděn na čtyřech základních školách a jednom víceletém gymnáziu. Školy byly vybrány subjektivně tak, aby byly zastoupeny školy z velkoměsta, krajského města, menšího města a vesnice. Dotazníkového šetření se zúčastnilo 216 žáků (131 dívek a 85 chlapců) ve věku 12-15 let.

\section{Výsledky}

$\mathrm{Na}$ základě polostrukturovaných rozhovorů s učiteli jsme zjistili hlavní kladné a záporné segmenty, které ovlivňují realizaci kurzů na školách. Většina učitelů řadí jízdu na kole mezi své nejoblíbenější pohybové aktivity. Z hlediska organizace cykloturistických výletů uvedli učitelé délku kurzu 1-5 dní. Ujetá vzdálenost byla průměrně $25 \mathrm{~km}$ za den, učitelé však poukazovali na nedostatečnou fyzickou připravenost žáků. Učitelé by si děti rádi prověřili předem, ale nedostávají k tomu prostor od vedení školy. Kurzů se účastnili žáci pátých až devátých tříd. Zájem o kurzy byl značný, jen minimální počet žáků zůstával doma. Trasy vyjížděk vedly především po cyklostezkách, lesních a polních cestách, popř. silnicích nižších tříd. Školy lze rozdělit na ty, kde učitelé hodlají pokračovat v organizování cyklovýletů, a ty, kde mají špatné zkušenosti, a opětovné pořádání kurzu odmítají.

Školy z první skupiny, jejichž žáci budou i nadále jezdit na kurzy, charakterizují hlavní důvody takto: Velký zájem žáků koresponduje se vstřícností vedení školy. Žádná ze škol však neposkytuje finanční prostředky na to, aby na kurz mohl jet větší než minimální nutný počet pedagogů, $\mathrm{v}$ čemž učitelé vidí problém. Dalším pozitivním jevem je poměrně nízká finanční náročnost (oproti např. lyžařským kurzům). Velkou oblibu u žáků i učitelů mají kurzy s cyklistickou náplní spojené s další sportovní nebo kulturně-poznávací činností.

Učitelé, kteří již kurzy organizovat nechtějí, uvádějí následující důvody: Nejzávažnějším argumentem se jeví být odpovědnost učitele za žáky. Počet žáků na jednoho pedagoga je podle nich př́iliš vysoký, a není tak v jejich silách mít přehled o všech žácích najednou. Riziko úrazu je v takové situaci př́liš vysoké. Učitelé si také stěžují na nezodpovědné chování žáků (nedodržování pravidel silničního provozu, ohrožování sebe i ostatních nebezpečnou jízdou apod.). Dalším argumentem je vysoká časová náročnost na př́pravu kurzu, která nebývá nijak oceněna ze strany vedení školy.

Z hlediska připravenosti žáků na realizaci výletu vidí učitelé značný problém v materiálním vybavení žáků (velikosti a kvalitě jízdního kola). Podle pedagogů za to mohou finanční možnosti rodičů a nedostatečné znalosti žáků i rodičů o možnostech výběru jízdního kola. Limitujícím faktorem, na kterém se shodli všichni učitelé, je fyzická zdatnost žáků. Děti podle nich nejsou zvyklé na déletrvající zátěž. Jak již bylo zmíněno, učitelé tělesné výchovy nenacházejí možnost, jak žáky na takovou zátěž připravit (organizování cvičných vyjížděk apod.). Prostor ve výuce však dostává teorie. Školy své žáky posílají na dopravní hřiště, samy jim organizují dopravní výchovu a před odjezdem na kurz prověřují jejich znalosti testováním. Důraz je kladen na pravidla silničního provozu a zvládnutí základních oprav jízdního kola.

Následující okruh otázek se týkal příčin nebezpečných situací při cykloturistických vyjížd’kách. Dotazovaní učitelé uvádějí, že žáci nemají problémy s dopravním značením. Potřebné znalosti získali na dopravním hřišti nebo při dopravní výchově. Potíže naopak vznikají v jízdě ve skupině. Často dochází k pádům zaviněným nebezpečným předjížděním nebo nedodržováním bezpečných rozestupů. Na vině bývají zejména chlapci, kteří se chtějí předvést a přeceňují své síly. Děvčata jsou klidnější a v tomto ohledu s nimi nebývají problémy. K častým pádům dochází také z přičiny nezvládnutí techniky jízdy. Žákům činí obtíže 
jízda na mokrém nebo blátivém povrchu a obecně v členitém terénu. $Z$ pohledu učitelů jsou tyto nedostatky v aktivní bezpečnosti žáků velkým problémem, protože trasy vyjížděk vždy vedou z největší možné části prŕrodou, mimo dobře udržované silnice, aby se cyklisté vyhnuli automobilovému provozu. Pedagogové považují právě automobily za největší riziko. Mají opakované zkušenosti s nervózními řidiči, kteří bezohlednou jízdou ohrožují celou skupinu cyklistů. Čím více cyklistů jede pohromadě, tím je situace nebezpečnější. Na každém kurzu dochází k pádům, většinou bez vážnějších následků. Časté jsou odřeniny a otoky. Někdy dochází i k závažnějším zraněním, jakými jsou zlomeniny nebo otřes mozku.

Pro náš výzkum byly potřebné také informace o tom, jak sami učitelé zajištují bezpečnost žáků. Přilba je na všech školách samozřejmostí, bez ní žák na kurz nesmí odjet. Její bezpečné připevnění na hlavě je učiteli kontrolováno a upravováno. Školy mají zkušenost s tím, že někteř́ žáci jezdí s nevyhovujícími přilbami. $\mathrm{Na}$ tuto skutečnost bývá pamatováno $\mathrm{v}$ př́pravě na kurz - přilby se kontrolují s dostatečným předstihem, aby mohla být zjednána náprava. Před výjezdem se provádí i základní kontrola technického stavu jízdního kola. Jak již bylo uvedeno, žáci jsou proškoleni ve zvládání drobných oprav, a pokud je to v jejich silách, opravují si nedostatky na svých kolech sami. Jedna ze škol po svých žácích před vícedenní vyjížd’kou vyžaduje potvrzení o kontrole kola v odborném servisu. Další činností ze strany učitelů je seznámení žáků s pravidly bezpečnosti na kurzu. Učitelé tak zároveň chrání sami sebe před př́ípadnými právními postihy při vzniku zranění. Pedagogové by ještě chtěli zavést povinné proškolení rodičů (o výběru kola a bezpečnostních pomůcek, o zásadách bezpečného ježdění na kole apod.), aby si mohli své děti na kurz připravit sami. Na to však v žádné ze škol nejsou podmínky. Veškeré ochranné prostředky musejí mít žáci vlastní, školy nekupují žádné vybavení, které by mohly půjčovat. Učitelé zajištují pouze vybavení lékárny a nářadí na drobné i větší opravy. Náhradní duše nebo lepení si žáci vozí své. Technická a fyzická připravenost žáků kontrolována není, s výjimkou kurzů, kde je nutné denně urazit kolem $70 \mathrm{~km}$. Takové se však pořádají zř́dka. Tyto kontroly by byly časově náročné a vedení škol nemá možnosti, jak je zařadit do plánů výuky.

Následující sled otázek směřoval k začleňování cyklistiky a cykloturistiky do běžného vyučování. Nejrozsáhlejší př́pravou je pro žáky dopravní výchova, kterou absolvují na prvním stupni nebo v nižších ročnících druhého stupně. V jejím rámci se učí řešit křižovatky, poznávat dopravní značení, bezpečnému chování cyklisty a chodce v silničním provozu. Dále probírají povinné vybavení jízdního kola, seznamují se s prvky pasivní bezpečnosti při cykloturistice a učí se, z jakých součástí se kolo skládá. Výuka je organizována formou běžných vyučovacích hodin, ale i projektů. Školy, které mají možnost poslat své žáky na dopravní hřiště, tak činí na prvním stupni. Jedna ze škol dopravní hřiště nevyužívá, nabízí však srovnatelnou výuku na svém vlastním pozemku za pomoci dopravní policie. Další vědomosti mohou získat žáci účastnící se dopravních soutěží. Hovoříme však pouze o několika vybraných dětech $z$ celé třídy. $V$ př́pravě na kurz je zahrnuto stručné opakování teorie z dopravní výchovy, která je doplněna o výuku základních oprav kola a bezpečného chování na kurzu. Výuka prvků aktivní bezpečnosti neprobíhá a ani v minulosti neprobíhala na žádné ze škol. Podle názoru učitelů by zájem o učení se technice jízdy měli spíše chlapci. $Z$ každé třídy, která absolvovala cyklistický kurz, by byli schopni vybrat několik žáků do té míry zapálených pro cyklistiku, že by chtěli absolvovat podobnou výuku. Nikdy by to však nebyla většina. Učitelé se domnívají, že takové kurzy by se naplnily, kdyby do nich mohly docházet děti $z$ více tříd. Na otázku, zda by se na škole našli učitelé ochotní vést výuku techniky jízdy na kole, odpovídali kladně zejména muži. Nechtěli by však z důvodu bezpečnosti mít na starosti velkou skupinu žáků (dle platných norem standardně 10 žáků na dva učitele).

Následujícím okruhem otázek jsme chtěli zjistit, jaký mají učitelé přehled o výukových materiálech cykloturistiky. Většinou se využívají učebnice a př́ručky pro učitele. Dětem jsou předkládány pracovní listy. Odborné časopisy s cyklistickou tématikou neodebírá žádná škola. Učitelé uvádějí, že případné výukové DVD by pro žáky bylo vhodnou pomůckou, obrazové zpracování techniky jízdy jednotlivce i skupiny se jim jeví jako velmi přínosné. Využili by jej v prrípravě na kurz nebo v př́ípadě vícedenního výletu na kurzu samotném.

Poslední oblastí našeho zkoumání byly názory učitelů na stav bezpečnosti př̀i provozování cykloturistiky v rámci školní výuky a případné návrhy na jeho zlepšení. Učitelé by v první řadě chtěli, aby na kurzy mohl jezdit početnější doprovod pedagogů. Vadí jim i vyskytující se neukázněnost žáků. Netýká se to pouze samotné doby jízdy, na několikadenních kurzech dochází k porušování večerky, a unavení žáci jsou druhý den méně pozorní a ostražití. Riziko pádu a vzniku úrazu se tak zvyšuje. V prvcích pasivní 
bezpečnosti problémy nebývají. Možnosti zvýšení bezpečnosti žáků na kurzu učitelé vidí ve větší postižitelnosti neukázněných žáků. Dále by přivítali více finančních prostředků na organizaci, např́klad zajištění většího počtu pedagogů a výukových materiálů.

Z dotazníkového šetření jsme vybrali pouze některé výsledky. Jedním ze základních ukazatelů oblíbenosti cykloturistiky je její výběr mezi ostatními sportovními aktivitami. Cyklistiku uvedlo $34,8 \%$, byla nejčastěji provozovanou aktivitou $38 \%$ dotázaných. $Z$ hlediska výběru kola využívá 145 respondentů horské kolo, přičemž vlastnictví kola vyvrátilo pouze 10 jedinců $\mathrm{z}$ dotazovaných.

Většina (119) z dotázaných uvedla, že se o kolo starají rodiče (seřízení, mytí, údržba), 60 žáků se o kolo stará samo. Odborný servis přitom každoročně využívá pouze 29,3\% dotazovaných, shodný počet dotázaných služby servisu nevyužilo nikdy.

V souvislosti s opravami jsme se dotazovali na dovednosti žáků. Nejvíce respondentů uvedlo, že dokáže nastavit výšku sedla. Bylo jich celkem 201. Naopak nejméně zvládanou opravou je lepení duše. Zalepit duši dokáže podle výsledků anketního dotazníku 68 respondentů. Nasazení spadlého řetězu opraví 173 žáků, nafouknout kolo umí 176 žáků a namazat řetěz zvládne 101 žáků ze všech zkoumaných. Na základě řízených rozhovorů jsme zařadili i otázky na četnost vyjížděk a jejich kilometrovou dotaci. Odpovědi korespondovaly s fyzickou vyspělostí žáků a jsou znázorněny v tab. 2 a 3.

Tab. 2 - Počet vyjížděk za týden

\begin{tabular}{|l|c|c|c|c|}
\hline počet vyjížděk za týden & abs. četnost & rel. četnost & abs. kumul. četnost & rel. kumul. četnost \\
\hline 6krát až 7krát & 18 & 0,084 & 18 & 0,084 \\
\hline 4krát až 5krát & 32 & 0,148 & 40 & 0,232 \\
\hline 2krát až 3krát & 88 & 0,407 & 128 & 0,639 \\
\hline 1krát & 61 & 0,282 & 189 & 0,921 \\
\hline nejezdím na kole & 17 & 0,079 & 216 & 1 \\
\hline
\end{tabular}

Tab. 3 - Najeté km za týden

\begin{tabular}{|l|c|c|c|c|}
\hline najeté $\mathrm{km}$ za týden & abs. četnost & rel. četnost & abs. kumul. četnost & rel. kumul. četnost \\
\hline více než 50 & 17 & 0,085 & 17 & 0,085 \\
\hline 31 až 50 & 33 & 0,166 & 50 & 0,251 \\
\hline 10 až 30 & 64 & 0,322 & 114 & 0,573 \\
\hline méně než 10 & 56 & 0,281 & 170 & 0,854 \\
\hline nevím & 29 & 0,146 & 199 & 1 \\
\hline
\end{tabular}

Položka číslo 13 anketního dotazníku zjištovala, v jakém prostř̌edí respondenti jezdí nejraději. Na výběr měli z pěti prostředí sestavených ordinální škálou. Všech pět prostředí měli oznámkovat jako ve škole podle toho, v kterých jezdí nejraději. V tabulce číslo 4 je vidět, že podle průměrné známky jsou nejoblíbenějším prostř̌edím lesní a polní cesty, mírný terén. Nejméně oblíbený je naopak těžký terén. U každého prostředí je tučně vyznačena nejčastěji obdržená známka.

Tab. 4 - Nejoblíbenější prostředí pro jízdu na kole

\begin{tabular}{|l|c|c|c|c|c|c|}
\hline prostředí & zn. 1 & zn. 2 & zn. 3 & zn. 4 & zn. 5 & prům. známka \\
\hline asfaltové silnice & 96 & 33 & 50 & 20 & 11 & 2,13 \\
\hline lesní a polní cesty, mírný terén & 107 & 33 & 44 & 21 & 5 & 1,97 \\
\hline těžký terén (např. hory) & 20 & 13 & 62 & 30 & 85 & 3,70 \\
\hline hřiště upravená pro kola & 32 & 34 & 77 & 36 & 31 & 3,00 \\
\hline cyklostezky & 57 & 47 & 72 & 19 & 15 & 2,47 \\
\hline
\end{tabular}


Tabulka číslo 5 uvádí, že nejčastějším prostředím pro jízdu na kole jsou pro žáky-respondenty asfaltové silnice $s$ průměrnou známkou 2,01, těsně následované lesními a polními cestami, mírným terénem s průměrnou známkou 2,08. Naopak nejméně často žáci jezdí na hřištích upravených pro kola, ta dostala průměrnou známku 3,70. Tučně vyznačené hodnoty ukazují nejčastější známku ve všech typech prostředí.

Tab. 5 - Nejčastější prostředí pro jízdu na kole

\begin{tabular}{|l|c|c|c|c|c|c|}
\hline prostředí & zn. 1 & zn. 2 & zn. 3 & zn. 4 & zn. 5 & prům. známka \\
\hline asfaltové silnice & 104 & 42 & 42 & 20 & 8 & 2,01 \\
\hline lesní a polní cesty, mírný terén & 96 & 46 & 34 & 32 & 6 & 2,08 \\
\hline těžký terén (např. hory) & 25 & 12 & 70 & 75 & 34 & 3,38 \\
\hline hřiště upravená pro kola & 9 & 10 & 74 & 68 & 55 & 3,70 \\
\hline cyklostezky & 24 & 22 & 63 & 81 & 24 & 3,25 \\
\hline
\end{tabular}

V položce číslo 19 anketního dotazníku měli žáci opět známkovat. Tentokrát udělovali známky podle toho, jak zvládají jízdu v předepsaných situacích. Pro volbu situací byla použita subjektivní škála. Průměrné známky v tabulce číslo 6 ukazují, že nejvíce si žáci věří v jízdě po asfaltu, nejméně pak př̀ překonávání překážek v terénu. Jízda v terénu v tomto hodnocení dopadla obecně hůře než jízda po asfaltu. Tučně je vyznačena nejčastější známka u každé situace.

Tab. 6 - Zvládání jízdy v různých situacích

\begin{tabular}{|l|c|c|c|c|c|c|}
\hline situace & zn. 1 & zn. 2 & zn. 3 & zn. 4 & zn. 5 & průměrná známka \\
\hline jízda po rovině po asfaltu & 180 & 11 & 12 & 3 & 4 & 1,29 \\
\hline jízda do kopce po asfaltu & 83 & 71 & 5 & 9 & 12 & 1,60 \\
\hline jízda z kopce po asfaltu & 177 & 11 & 17 & 3 & 2 & 1,30 \\
\hline řešení křižovatek & 45 & 71 & 63 & 10 & 21 & 2,48 \\
\hline jízda do kopce v terénu & 43 & 57 & 75 & 23 & 12 & 2,54 \\
\hline jízda z kopce v terénu & 104 & 54 & 37 & 10 & 5 & 1,85 \\
\hline jízda v blátě & 59 & 49 & 61 & 33 & 8 & 2,44 \\
\hline skákání přes (malou) překážku & 37 & 48 & 54 & 39 & 32 & 2,91 \\
\hline zatáčení v terénu & 86 & 65 & 42 & 8 & 9 & 2,00 \\
\hline měnění převodů & 133 & 38 & 17 & 10 & 12 & 1,71 \\
\hline
\end{tabular}

Dále jsme zkoumali pády z kola. Nejčastější odpovědí bylo 1 až 2 pády s četností 102.54 respondentů z 209 odpovídajících uvedlo, že z kola nepadá. Více než 30krát za rok z kola spadne 2,4\% respondentů, alespoň $16 \mathrm{krát}$ spadne $3,4 \%$, alespoň 6krát spadne $7,7 \%$ respondentů. Dále alespoň $3 \mathrm{krát}$ za sezónu spadne z kola $25,4 \%$ respondentů a alespoň 1 krát za sezónu spadne 74,2 \% odpovídajících.

Další otázkou jsme zjištovali, zda a proč by měl respondent zájem účastnit se školního kurzu s cyklistickou náplní. Žáci často volili více možností a mohli i sami některé doplnit. $Z$ nabízených možností byla nejčastěji vybírána zábava s kamarády, a to 123krát. 45 žákủ by na kurz nejelo. Na obr. 1 jsou zobrazeny absolutní hodnoty u všech možností výběru odpovědi. 


\section{Příčiny zájmu o kurz}

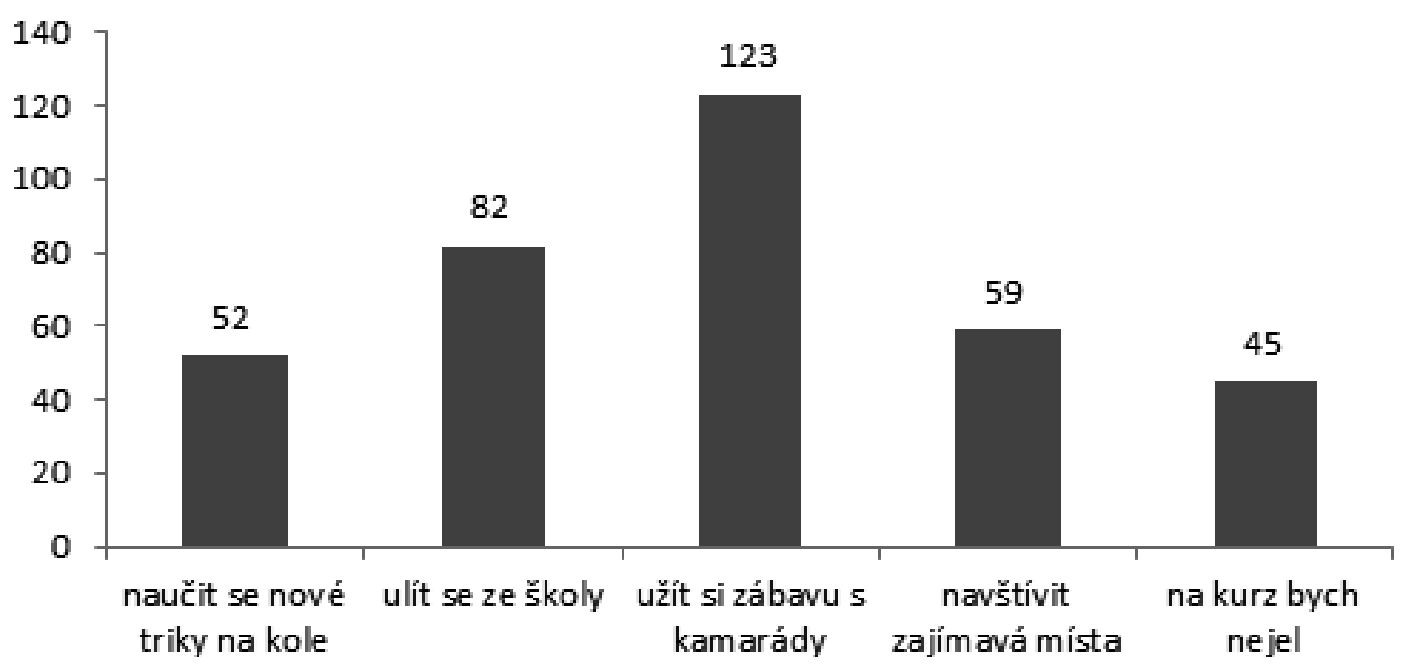

Obr. 1 - Příčiny zájmu o kurz

Poslední byla otázka o případném zájmu o školní výuku jízdy na horském kole mimo kurz. Odpověd”,ano“ vybralo 79 z 214 odpovídajících, tedy 36,9\%. Zbylých 135 respondentů, což je 63,1\%, volilo odpověd” „ne“.

\section{Diskuze}

Cykloturistika je velmi oblíbeným a rozšířeným sportem mezi žáky i mezi učiteli tělesné výchovy. Většina respondentů má své kolo, nejčastěji horské. Mírný terén je častým prostředím pro cykloturistiku žáků, i trasy školních kurzů podle výpovědí učitelů procházejí z největší části mírným terénem.

Analýza videozáznamu ukazuje na častý výskyt chyb v technice jízdy v terénu. Tento výsledek se shoduje s výpověd’mi učitelů, kteří rovněž poukazují na nedostatečný stav dovedností žáků v jízdě na kole. Žáci své technické dovednosti naopak hodnotí spíše lepšími známkami, nicméně v porovnání s jízdou na komunikaci se v terénu cítí jako slabší jezdci. Rozpor mezi tím, jak žáci hodnotí své dovednosti, a výsledkem pozorování je častým jevem. Např́íklad při měnění převodů se respondenti cítí velmi jistěe, analýza videozáznamu však odhaluje, že při této činnosti vzniká nejvíce chyb. Jako možná náprava se nabízí zavedení výuky jízdy v terénu. Učitelé se domnívají, že o takovou výuku by žáci měli zájem, vždy by jich však bylo méně než polovina standardní kapacity tř́ídy. Výsledek anketního dotazníku to potvrzuje. Zájem by byl o praktickou výuku (skákání přes překážku, sjezdy, výjezdy apod.). Teorii by při výuce cyklistiky chtělo jen $23 \%$ respondentů. Podle učitelů je však cyklistika na školách probírána pouze teoreticky, pro praktickou výuku (s výjimkou oprav kola) nejsou podmínky. Riziko úrazu lze tedy spatřovat $\mathrm{v}$ nedostatečné technické př́pravě.

Většina žáků ráda jezdí na školní kurzy. Chtějí si na nich hlavně užít zábavu s kamarády. Učitelé znají zájem žáků o školní cykloturistiku, zároveň však poukazují na jejich nekázeň při cykloturistických výletech. Ve spojení s nízkým počtem učitelů představuje tato skutečnost další bezpečnostní riziko.

Seřízení kola v odborném servisu před absolvováním kurzu po svých žácích vyžaduje jediná ze zkoumaných škol. Jen malý podíl respondentů pravidelně nechává své kolo takto kontrolovat. Odpovídá to informacím od učitelů, které uvádějí, že žáci mají kola často ve špatném stavu. Zde rovněž spatřujeme bezpečnostní riziko.

Na základě výzkumu popsaného v této práci nyní můžeme charakterizovat stav bezpečnosti provozování školní cykloturistiky. Rizika úrazů spatřujeme v nedostatečné technické připravenosti žáků na jízdu v terénu. Další nebezpečí je spojeno se nízkou žákovskou kázní na kurzech a s minimálními možnostmi škol posílit dohled nad žáky. Riziko vzniku úrazu hrozí i jako následek špatného technického stavu kol 
žáků. Cílenou výukou by žáci mohli získat dovednosti k jízdě na kole v oblíbených terénech, a opustit vyhledávané asfaltové komunikace, kde se zvyšuje riziko úrazu kontaktem s motorovými vozidly. Rizika plynoucí z objektivních prř́čin lze tréninkem cyklistických dovedností jízdy na kole eliminovat. Výsledky se shodují ve velké míře s výzkumy, které byly součástí závěrečných prací (Kalich 2008, Toušová 2009, Hetmer 2009, Kádrlová 2010, Koláček 2010, Karas 2010, Andrések 2010).

\section{Závěr}

Pro získání dostatečného množství dat potřebných pro výzkum stavu aktivní bezpečnosti při provozování cyklistiky a cykloturistiky v rámci školní výuky jsme použili empirické metody pozorování, nestrukturovaný rozhovor a anketní dotazník. Rozdělení výzkumu na tyto tři části se ve výsledku ukázalo jako př́nosné. Měli jsme možnost srovnávat informace z různých zdrojů. Nejdříve jsme pořídili videozáznam k pozorování. Provedli jsme jeho analýzu a na základě zjištěných poznatků sestavili anketní dotazník pro žáky a provedli rozhovory s učiteli tělesné výchovy. $Z$ analýzy videozáznamu vyplynuly nejčastější chyby, kterých se cyklisté dopouštějí při jízdě v terénu. Pro záznam a vyhodnocení získaných dat jsme použili subjektivní škálu hodnocení. Natočili jsme celkem 91 záznamů techniky jízdy jednotlivců, což se jevilo jako dostatečný počet. Když jsme je však roztřídili do skupin podle toho jakou situaci (sjezd, výjezd, zatáčení apod.) bylo možné u jednotlivých záznamů zkoumat, zjistili jsme, že pro zkvalitnění výsledků pozorování by bylo zapotřebí natočit záznamů ještě více.

$\mathrm{S}$ učiteli tělesné výchovy jsme prováděli nestrukturované rozhovory. Data z nich získaná jsme hodnotili jako dostačující pro účely našeho výzkumu. Domníváme se, že by bylo vhodné provést další rozhovor s učiteli na základě výsledků anketního dotazníku. Učitelé by tak měli možnost reagovat na data získaná od svých žáků. Při plánování výzkumu jsme však tuto možnost nezahrnuli do harmonogramu, a ani později jsme z časových důvodů další rozhovory neprováděli.

Cykloturistika má své místo ve výuce na středních školách. Pro získání komplexnějších výsledků by bylo vhodné provést obdobný výzkum i na nich. K němu by mohl posloužit námi vytvořený videozáznam, i rozhovory s učiteli by se mohly provádět stejně. Změnit by se však musely některé položky anketního dotazníku, který svým charakterem a složitostí odpovídá úrovni žákủ druhého stupně základních škol, popř́ípadě nižších ročníků víceletých gymnázií.

Zjistili jsme, že jednou z přičin vzniku zranění při školní cykloturistice je nedostatečná technická připravenost žáků. Problémy jim činí zejména technika jízdy v terénu, dále pak jízda ve skupině. Výuka těchto činností na školách probíhá pouze teoreticky, což podle výsledků výzkumu není dostatečné. Žáci se ve škole naučí pravidla silničního provozu, která podle dat získaných z rozhovorů dobře zvládají. $\mathrm{Na}$ školních kurzech s cyklistickou náplní je však používají daleko méně než techniku jízdy v terénu a ve skupině. Mírný terén totiž učitelé volí pro trasy vyjížděk nejčastěji. Je to právě proto, aby se s žáky vyhnuli silničnímu provozu. Proto navrhujeme zařadit praktickou výuku jízdy v terénu a ve skupině, spolu s teoretickou výukou pravidel silničního provozu. Tato kombinace praktické a teoretické výuky by podle našeho názoru mohla vést ke zvýšení bezpečnosti cyklistů.

Učitelé uvádějí, že nemalá bezpečnostní rizika s sebou přináší jednak neukázněné chování žáků na kurzech, jednak malý počet dospělých osob, které je doprovázejí. Domnívají se, že snížení maximálního počtu žáků-cyklistů na jednoho učitele by mělo za následek zlepšení kázně žákủ. Toho lze dosáhnout úpravou směrnice školy (současný poměr je 2 pedagogové na 10 žáků). Tím by opět došlo k podpoře bezpečnosti žáků-cyklistů. Dalším naším návrhem je proto posílení pedagogického dozoru na kurzech. Akceptujemeli finanční možnosti škol, které nemají prostředky na zaplacení více pedagogů na kurzu, jeví se jako možné východisko dobrovolnictví ze strany rodičů nebo jiných dospělých př́ibuzných žáků. Situaci lze také vyřešit např́klad zapojením studentů $V S ̌$, kteří na škole působí v rámci své pedagogické praxe.

Naprostá většina respondentů z řad žáků uvedla, že má své vlastní jízdní kolo a že na něm zvládá drobné opravy. Odborný servis však pravidelně navštěvuje jen malá část $z$ nich. Podle informací od učitelů to má za následek často se vyskytující špatný technický stav kol žáků. Jízda na takovém kole znamená zvýšená bezpečnostní rizika. Jako opatření vedoucí ke zlepšení této situace navrhujeme školám uložit žákům povinnost navštívit odborný cykloservis alespoň před vícedenním kurzem. 


\section{Literatura}

ANDRÉSEK, F. Zjištování cyklistických dovedností u dětí mladšího školního věku. Bakalářská práce, Masarykova univerzita, Fakulta sportovních studií, 2010, $50 \mathrm{~s}$.

BOŘEK, P. Nedbalostní dopravní nehody a vybrané otázky jejich dokazování. Bakalářská práce, Masarykova univerzita, Právnická fakulta, 2007, 45 s.

HETMER, P. Role cykloturistiky jako sportovní aktivity u dětí staršího školního věku. Diplomová práce, Masarykova univerzita, Fakulta sportovních studií, 200959 s.

CHRÁSKA, M. Metody pedagogického výzkumu: základy kvantitativního výzkumu. 1. vyd. Praha: Grada Publishing, a. s., 2007. 365 s. ISBN 978-80-247-1369-4.

JEŘÁBEK J., TUPÝ, J. a kol. Rámcový vzdělávací program pro základní vzdělávání, VÚP Praha, 2007, 126 s. Dostupný z: http://old.vuppraha.cz/soubory/RVPZV_2007-07.pdf

JEŘÁBEK J., KRČKOVÁ, S. HUČÍNOVÁ, L. a kol. Rámcový vzdělávací program pro gymnázia, VÚP Praha, 2007, 101 s. Dostupný z: http://vyuka.jazyku.cz/i/File/RVP_G.pdf

KÁDRLOVÁ, R. Možnosti cykloturistiky v oblasti Krkonoše-východ. Diplomová práce, Masarykova univerzita, Fakulta sportovních studií, 2010. $78 \mathrm{~s}$.

KALICH, R. Organizace cykloturistických zájezdů na základních a středních školách, Bakalářská práce, Masarykova univerzita, Fakulta sportovních studií, 2008. 49 s.

KARAS, R. Prevence úrazů při školní cyklistice na druhém stupni základních škol a středních školách. Diplomová práce, Masarykova univerzita, Fakulta sportovních studií, 2010. $98 \mathrm{~s}$.

KOLÁČEK, M. Možnosti cykloturistiky v oblasti Vsetínských vrchů. Diplomová práce, Masarykova univerzita, Fakulta sportovních studií, 2010. 97 s.

Ministerstvo zdravotnictví ČR Národní akční plán prevence dětských úrazů na léta 2007-2017 [cit. 201103-18] Dostupný z: http://www.mzcr.cz/Odbornik/dokumenty/narodni-akcni-plan-prevence-detskych-urazu-usneseni-vlady_2047_1009_3.html

ONDRÁČEK, J., HŘEBÍČKOVÁ, S. Cykloturistika. 1. vyd. Brno: Masarykova univerzita. 2007. 123 s.

PALÁN, J. Bezpečnost provozování cykloturistiky v rámci výuky na ZŠ a SŠ. Diplomová práce, Masarykova univerzita, Fakulta sportovních studií, 2011. $74 \mathrm{~s}$.

PUCHER, J. BUEHLER, R. Making cycling irresistible: Lessons from the Netherlands, Denmark and Germany, In: Transport Reviews, 28/4 2008, s. 495-528

TOUŠOVÁ, K. Role cykloturistiky jako sportovni aktivity u dětí staršího školního věku. Diplomová práce, Masarykova univerzita, Fakulta sportovních studií, 2009. 49 s.

VYŠKOVSKÝ, J. Turistika a sporty v př́rodě. 1. vyd. Brno: Masarykova univerzita v Brně, 1997. $98 \mathrm{~s}$.

WEIERMAIR, K. BIEGER, T. Tourism Education in Austria and Switzerland: Past Problems and Future Challenges In: Journal of teaching in Travel and Tourism 5/1-2 2005, s. 39-60 